Agro-Science Journal of Tropical Agriculture, Food, Environment and Extension Volume 19 Number 4 (October 2020) pp. 30 - 36

TSSN 1119-7455

\title{
PERCEIVED EXTENSION NEEDS OF RUBBER PRODUCTION AMONG FARMERS IN DELTA STATE, NIGERIA
}

\author{
"Adebayo S.A., Ogunlade I. and Ede E.E. \\ Department of Agricultural Extension \& Rural Development, \\ Faculty of Agriculture, University of Ilorin, Kwara State, Nigeria \\ "Corresponding author's email: sijuadeadebayo@yahoo.com
}

\begin{abstract}
The need to develop a sustainable exploitation system for the Nigerian rubber farmers requires that extension services should be available to assist the farmers in specific areas that can help them function effectively and improve productivity. The study investigated the perceived extension needs of rubber production farmers in Delta state Nigeria. The specific objectives of the study were to determine sources of information on rubber production, varieties of rubber clones cultivated by the respondents, perceived extension needs of rubber farmers, and constraints to rubber production. A multi stage sampling technique was used to select 120 rubber farmers as respondents for the study. Data were analysed using frequency, percentages, means and Pearson Product Moment correlation analysis. Results showed that majority of the respondents (85.5\%) were male, married (83.3\%) and had average farming experience of 14 years. The NIG801 and NIG800 varieties were the local clones majorly cultivated and the GT1 and PB217 varieties were the exotic clones majorly cultivated. Findings also showed that respondents need production information on use of formic acid for latex coagulation (66.7\%), use of ammonia for latex preservation (73.3\%) and marketing information (60.8\%). The constraints indicated by the respondents were problem of land tenure (81.7\%), lack of adequate credit facilities $(70 \%)$, fire outbreaks (72.5\%) among others. The result of the hypothesis showed that age $(r=0.199)$ had a positive significant relationship with farmers' extension needs. It was recommended that extension personnel should be trained on techniques of rubber production in order to deliver effectively to the farmers.
\end{abstract}

Key words: extension needs, rubber, farmers, Delta, Nigeria

\section{INTRODUCTION}

Rubber is a perennial dicotyledonous plant which belongs to the family Euphorbiaceae. It is grown commercially over millions of hectares and is capable of being exploited for over 35 years. Nigeria has a vast potential for the production of rubber especially in many of the southern States in the country. Aigbokaen et al. (2000) and Abolagba and Giroh (2006) noted that rubber can be grown extensively in Edo, Delta, Abia, Akwa Ibom, Cross River, Imo, Ebonyi and River States where the annual rainfall ranges between $1800 \mathrm{~mm}$ and $2000 \mathrm{~mm}$ per annum.

One of the most important parts of the rubber tree from the grower's perspective is the bark, which contains the latex producing tissues (Delabarre and Serier, 2000). The rubber latex is very useful as it can be processed into secondary products such as crepe rubber, crumb rubber and sheet rubber for onward processing into finished products. Rubber contributes three functions in the Nigerian economy in terms of providing raw materials for agro based industries, foreign exchange earnings and in the provision of employment. The latex from rubber can be used in the automobile industry in the production of tyres, transmission belts, and seats amongst others. The latex is also used for the manufacture of adhesives, baby feeding bottle teat, balloons, industrial gloves among others (Abolagba et al., 2003). Moreover, Iyayi et al. (2008) reported that the seeds produced by the rubber tree (Hevea brasiliensis) contains valuable oil which has potential industrial application in the production of soap, cosmetics, paints, glazing putty while the seed cake left after the extraction of the oil has potential application in the formulation of livestock feeds and as nitrogenous fertilizer.

However, there has been a general decline in rubber production in the past decades both in area of production and in total output generally. The decline in production of rubber has been linked to the laborious production methods majorly used by small holder rubber farmers, the use of low quality planting materials, infrequent maintenance and poor tapping methods, poor marketing organization, high costs of inputs, lack of adequate market information, and low application of relevant technologies among others (Giroh et al., 2013). Moreover, the use of synthetic rubber has contributed to the decrease in the production of rubber in recent years. 
Agricultural extension service is widely recognized as the mechanism for the delivery of proven information and advice to farmers for improved productivity. Agricultural information dissemination is crucial to the productivity of farmers and makes them learn about those things which they are not aware of (Banmeke and Olowu, 2005). However, different categories of household and individual have different information needs, and their current expressed need for and potential access to information sources may also be different. Pierre-André et al. (2010) found out that rubber farmer' highly demanded areas for training were production of planting materials, tapping techniques, improved agricultural techniques and accurate preparation of stimulants. The transformation of traditional or peasant agriculture of farmers must of necessity emphasize the training and education of rural farmers. Therefore, the objectives of the study are to describe the socio economic characteristics of rubber farmers in the study area; determine rubber farmer's sources of information; identify the varieties of rubber cultivated in the study area; examine the areas of rubber production where farmers require information and identify perceived constraints to production by farmers in the study area. The hypothesis is, there is no significant relationship between socio economic characteristics of the farmers and their perceived extension needs.

\section{MATERIALS AND METHODS}

\section{Study Area}

The study area is Delta State located between latitude $5^{\circ} 00^{\prime}$ and $6^{\circ} 30^{\prime} \mathrm{N}$ of the equator and longitude $5^{\circ}$ $00^{\prime}$ and $6^{\circ} 45^{\prime} \mathrm{E}$ of the Greenwich meridian. The State has a land area of $17,440 \mathrm{~km}^{2}$; about one-third of this is swampy and waterlogged. There are 25 local government areas (LGAs) in the State with a population of 4,098,391 people (NPC, 2006). The State has a tropical climate marked by dry and rainy seasons. The rainy season starts in April and ends in October. The dry season starts in November and ends in March. The rainfall ranges from 1905 to $2660 \mathrm{~mm}$ monthly. The temperature ranges from $240 \mathrm{C}$ to $340 \mathrm{C}$ with an average of $300 \mathrm{C}$ (Delta State Ministry of Agriculture, 2000; Ike, 2010). Crops such as yam, cassava, maize, oil palm, rubber and cocoa and livestock such as cattle, sheep and goat are the main products of the farmers.

\section{Sampling Procedure and Sample Size}

A multi stage sampling technique was employed to select respondents for the study. The first stage involved the purposive selection of the central and north ADP zones due to concentration of rubber plantations in these zones. The second stage involved the purposive selection of three LGAs from the north zone and two LGAs from the central zone. The third stage involved the systematic random selection of the respondents from the five LGAs based on the sampling frame of registered rubber farmers in the selected LGAs. A percentage range from $13-40 \%$ was used to select respondents from the LGAs. 23 farmers were selected from Sapele, 24 from Ughelli north LGA, 23 from Aniocha South, 25 from Ika north and 25 from Ukuani LGAs. A total of 120 farmers were selected from 591 registered farmers as the sample size for this study.

\section{Data Analysis}

Data collected were analysed using simple descriptive tools such as frequency, percentages and means. Pearson product moment correlation (PPMC) was used to test the hypothesis.

\section{RESULTS AND DISCUSSION}

\section{Socio-Economic Characteristics of Rubber} Farmers in the Study Area

Table I shows that $32.5 \%$ of the respondents were between 41 and 50 years of age while $40 \%$ of the respondents were within the age range of 51-60 years. The mean age of the respondents was approximately 52 years which showed that the respondents were relatively middle aged. This result agrees with the views of Abolagba et al. (2003) who noted that rubber farmers consisted mainly of the aged category. This calls for efforts to be directed towards encouraging younger farmers to embark on rubber production activities. Majority of the respondents were male $(85.8 \%)$. This is an indication that rubber production is male dominated. Furthermore, the majority of the respondents were married $(83.3 \%)$ and had secondary education $(61.7 \%)$. It could be deduced that the respondents were fairly literate and this can be an advantage to information seeking and adoption of improved technologies. The result is in line with Idrisa et al. (2008) that found that educational level of the farming household range between primary and secondary education. The findings of Agwu (2004), have shown that education positively influence adoption of technologies. Also, $44.2 \%$ of the respondents had farming experience of between 11 and 15 years, $41.7 \%$ of the respondents cultivated between 2.5 and 3 hectares while mean household size was 7 people. This implies that the farmers had small farm holdings and may have access to family labour for other farm tasks.

The result is in support of Akukwe (2020) that found that agrarian communities have fairly household size. Finally, the results indicate that $80 \%$ of the respondents financed their rubber farming through personal savings. This implies that personal savings is a major source of finance for carrying out farming activities. This result is consistent with the work of Banmeke and Omoregbee (2009) that identified inadequate credit as one of the major problems of rubber farmers in Edo and Delta States of Nigeria. 
Sources of Information on Rubber Production The data in Table 2 show that the major sources of production information indicated by the respondents were neighbours and friends $(85.8 \%)$, contact farmers (91.7\%), farm groups/associations $(88.3 \%)$, family (65.8\%), ADP extension officers (95\%), and also mobile phones $(60.8 \%)$. Oladele (2006) noted that friends/relatives, radio and television are the important sources from where farmers obtain agricultural information. The respondents apparently rely more on fellow farmers and family friends for information about farming. They also make use of mobile phones and ADP extension officers. Extension agents could therefore leverage on some of these informal source channels such as contact farmers and farm groups or associations to pass information to the farmers.

The use of ADP extension officers (95\%) as a source of information indicated that the farmers had contact with extension agents. However, judging from the needs of the farmers, it can be deduced that the extension officers do not give them adequate information regarding rubber production technologies. This might be due to resource constraints by extension officers as reported by McDonaugh (2004) that at local level, extension officers are usually almost as resource constrained as the farmers they work with.

Rubber Clone Varieties Grown by the Respondents Table 3 shows the results of rubber clone cultivated by the respondents. Majority $(67.5 \%)$ of the respondents cultivated the NIG801 clone of the local variety, $50 \%$ also cultivated the NIG 800 variety which were mostly obtained from the rubber research institute of Nigeria at Benin City. This result is in line with Okunlola (2010) that reported that NIG 800 variety was mainly adopted and planted by growers in Delta state out all the varieties introduced to them. Moreover, Omokhafe and Nasiru (2004) reported that NIG 800 has ability to withstand wind damage and resistance to diseases. From the exotic clones, majority of the respondents $(66.7 \%)$ cultivated the GT 1 clone while 29.2\% cultivated the PB 217 which was mostly obtained at Rubber Estates Nigeria limited in Delta State. The farmers indicated the need for mixing both the local and exotic clones because most of the local clones do not give enough yield.

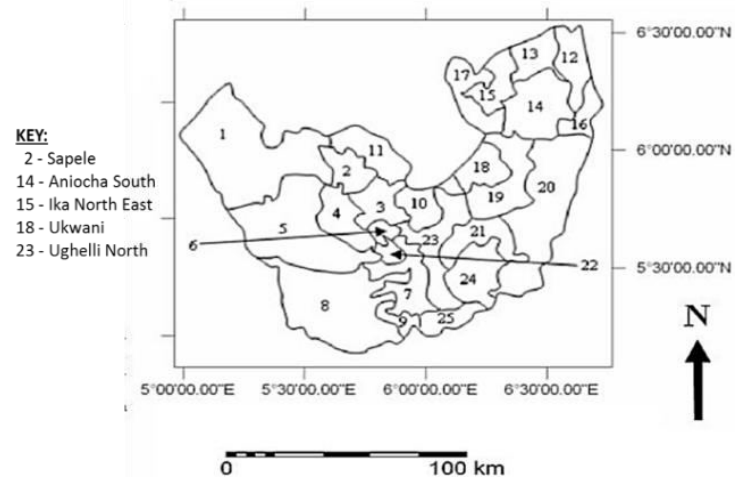

Figure 1: Map of Delta State showing the LGAs of the study Adapted from: Omo-Irabor and Olobaniyi (2013)
Table 1: Socio-economic characteristics of rubber farmers in the study area $(n=120)$

\begin{tabular}{|c|c|c|c|}
\hline Variables & Frequency & Percentage & Means \\
\hline \multicolumn{4}{|l|}{ Age (years) } \\
\hline $30-40$ & 15 & 12.5 & \\
\hline $41-50$ & 39 & 32.5 & 52 years \\
\hline $51-60$ & 48 & 40.0 & \\
\hline $61-70$ & 18 & 15.0 & \\
\hline \multicolumn{4}{|l|}{ Gender } \\
\hline Male & 103 & 85.8 & \\
\hline Female & 17 & 14.2 & \\
\hline \multicolumn{4}{|l|}{ Educational Level } \\
\hline Adult Education & 2 & 1.7 & \\
\hline Primary Education & 10 & 8.3 & \\
\hline Secondary Education & 74 & 61.7 & \\
\hline Tertiary Education & 34 & 28.3 & \\
\hline \multicolumn{4}{|l|}{ Marital Status } \\
\hline Single & 12 & 10.0 & \\
\hline Married & 100 & 83.3 & \\
\hline Divorced & 5 & 4.2 & \\
\hline \multirow{2}{*}{\multicolumn{4}{|c|}{ Farming Experience }} \\
\hline & & & \\
\hline $1-5$ & 8 & 6.7 & \\
\hline $6-10$ & 29 & 24.2 & \\
\hline $11-15$ & 53 & 44.2 & 14 years \\
\hline 16 and above & 30 & 25.0 & \\
\hline \multicolumn{4}{|l|}{ Farm Size } \\
\hline $0.5-1$ & 9 & 7.5 & \\
\hline $1.5-2$ & 52 & 43.3 & \\
\hline $2.5-3$ & 50 & 41.7 & 2.5 \\
\hline $3.5-4$ & 5 & 4.2 & hectares \\
\hline Above 5 & 4 & 3.3 & \\
\hline \multicolumn{4}{|l|}{ Household Size } \\
\hline $1-5$ & 55 & 45.8 & \\
\hline $6-10$ & 65 & 54.2 & 7 \\
\hline \multicolumn{4}{|l|}{ Source of Finance } \\
\hline Personal Savings & 97 & 80.8 & \\
\hline Loans from Banks & 10 & 8.3 & \\
\hline Cooperative & 9 & 7.5 & \\
\hline Friends and & 4 & 3.3 & \\
\hline Relatives & & & \\
\hline
\end{tabular}

\section{Perceived Extension Needs of Rubber Production Farmers}

Table 4 shows the areas of rubber production where farmers indicated the need for extension services. The results showed that the use of ammonia for preservation of latex with mean score (2.71), use of formic acid for coagulation of latex (2.62), marketing information (2.59), pest and disease control measures (2.47), tapping techniques (2.44); were amongst the areas of rubber production where the farmers indicated the need for extension services. This result is in line with the findings of Banmeke and Omoregbe (2009) who reported that the use of Ethel to stimulate latex production, use of ammonia for preservation and use of herbicides were some of the rubber technologies that were never adopted by rubber farmers in the study area. This could explain the need for more extension delivery in these areas. Furthermore, the use of clean coagulating pan with a mean score of (2.52) was one of the areas that farmers indicated the need for extension services and this agrees with the findings of Otene et al. (2011) that few of the respondents practice cleaning of latex cup before tapping and coagulation pans. It 
Table 2: Distribution of respondents according information source and frequency of usage

\begin{tabular}{|c|c|c|c|c|c|}
\hline Information source & Yes $(\%)$ & No $(\%)$ & Regularly (\%) & Often $(\%)$ & Rarely (\%) \\
\hline Neighbours and Friends & $103(85.8)$ & $17(14.2)$ & $80(66.7)$ & $25(20.8)$ & $15(12.5)$ \\
\hline Family & $79(65.8)$ & $41(34.2)$ & $61(50.8)$ & $21(20.8)$ & $34(28.3)$ \\
\hline Contact farmers & $110(91.7)$ & $10(8.3)$ & $89(74.2)$ & $19(15.8)$ & $12(10.0)$ \\
\hline Farm groups/associations & $106(88.3)$ & $14(11.7)$ & $90(75.0)$ & $17(14.2)$ & $13(10.8)$ \\
\hline Workshops/seminars & $40(33.3)$ & $80(66.7)$ & $19(15.0)$ & $35(29.2)$ & $67(55.8)$ \\
\hline ADP extension officers & $114(95.0)$ & $6(5.0)$ & $93(77.5)$ & $20(16.7)$ & $7(5.8)$ \\
\hline RRIN extension officers & $41(34.2)$ & $79(65.8)$ & $16(13.3)$ & $24(20.0)$ & $80(66.7)$ \\
\hline Mobile phones & $73(60.8)$ & $47(39.2)$ & $54(45.0)$ & $17(14.2)$ & $49(40.8)$ \\
\hline Television & $37(30.8)$ & $83(69.2)$ & $14(11.7)$ & $16(13.3)$ & $90(75.0)$ \\
\hline Newspaper & $32(26.5)$ & $88(73.3)$ & $13(10.8)$ & $15(12.5)$ & $92(76.7)$ \\
\hline Radio & $21(17.5)$ & $99(82.5)$ & $4(3.3)$ & $13(10.8)$ & $103(85.8)$ \\
\hline Internet & $17(14.2)$ & $103(85.8)$ & $2(1.7)$ & $15(12.5)$ & $103(85.8)$ \\
\hline
\end{tabular}

Source: Field Survey, 2016

Table 3: Distribution of respondents according to varieties of rubber cultivated

\begin{tabular}{llcc}
\hline Varieties & & Frequency & Percentages \\
\hline Local Clones & RRIN 500 & 30 & 25.0 \\
& RRIN 600 & 31 & 25.8 \\
& NIG 800 & 60 & 50.0 \\
& NIG 805 & 34 & 28.3 \\
Exotic Clones & NIG 801 & 81 & 67.5 \\
& IRCA 41 & 4 & 3.3 \\
& IRCA 209 & 4 & 3.3 \\
& IRCA 18 & 11 & 9.2 \\
& IRCA 109 & 20 & 16.7 \\
& IRCA 317 & 1 & 0.8 \\
& GT 1 & 80 & 66.7 \\
& RRIC 100 & 14 & 11.7 \\
& IAN 710 & 1 & 0.8 \\
PB 217 & 35 & 29.2 \\
PB 260 & 1 & 0.8 \\
\hline
\end{tabular}

*Multiple Responses Source: Field Survey, 2016

is imperative that latex from tree obtained by means of tapping, collection and bulking of coagula as well as materials used for such operations, are hygienically free from contaminations enunciated by Giroh et al. (2006). Pest control measure with a mean score of (2.47) was amongst the areas identified by the farmers for extension services. This agrees with the findings of Otene et al. (2011), who reported that only few of the respondents made use of chemicals (for example, pesticide) in their plantation. Most of the farmers complained of termite and ant infestation in their plantations, but they do not have chemicals to treat them and the result is the death of the rubber trees and low yield, hence the need for extension services in this area.

Recommended planting space with mean score of (2.20), use of agrochemicals (2.24), intercropping with arable crops (1.69); all recorded a lower mean scores indicating moderate extension needs. This could be attributed to the farmer's relatively high average farming experience which could have made the respondents more familiar with agroforestry systems, recommended planting space and time, and the use of some agrochemicals to a good extent. This agrees with the views of Ogwuche et al. (2012) who noted that intercropping rubber with arable crops has been found to be economically viable, in that the farmers obtain revenue from the sales of the crops while waiting for the maturity of the trees before the commencement of tapping.
Moreover, result also indicated a higher annual increase in girth of rubber intercropped compared to the sole rubber plantation. This may be due to increase in organic matter content as a result of residues from the intercropped plants after harvest which promote soil aeration and possible increase in soil nutrients required for the rubber growth and development. It could also be due to complementary of species interaction (Esekhade, 2003).

\section{Constraints to Rubber Production}

Table 5 reveals the constraints to rubber production as indicated by the respondents. The results show that problem of small farm size/land tenure, lack of adequate credit facilities, fire outbreaks on plantation, inadequate storage facilities, high cost of labour, unavailability of latex processing implements, low yield, low market prices were some of the major constraints to rubber production in the study area. This agrees with some of the findings of Osiebe (1999) that lack of good marketing channels, lack of capital, low yield and lack of government incentives were among the major problems facing farmers in rubber production. Agwu (2004) also reported that poor knowledge of rubber management, unavailability of improved rubber technologies, and inadequate capital were some of the constraints facing rubber production in south western Nigeria.

Problem of land tenure/small farm size with mean score (2.77) was a major constraint identified by the farmers. This is probably due to the land tenure systems in Nigeria which is still largely customary and this does not allow for much expansion. This finding agrees with Delabarre and Serier (2000) who reported that rubber cultivation in Nigeria is mainly by small-scale farmers. Adoption of an innovation may be affected by small hectares and might be a disincentive in the acquisition of credit facilities from commercial banks.

Lack of adequate credit facilities with mean score (2.67) was the second most important and significant constraint of rubber farmers. Rubber production is both labour and capital intensive and so requires a large capital; inadequate access to credit would limit rubber production expansion. This result is consistent with Banmeke and Omoregbee (2009) that identified inadequate credit as one of the major problems of rubber farmers in Edo and Delta States of Nigeria. 
Table 4: Distribution of the respondents according to perceived needs of rubber production

\begin{tabular}{lccccc}
\hline Technical information & Not Needed (\%) & Needed (\%) & Highly needed (\%) & Mean & Rank \\
\hline Use of agro chemicals & $8(6.7)$ & $75(62.5)$ & $37(30.8)$ & 2.24 & $10^{\text {th }}$ \\
Use of ethel to stimulate latex yield & $5(4.2)$ & $58(48.3)$ & $57(47.5)$ & 2.43 & $7^{\text {th }}$ \\
Use of improved cultivars from RRIN & $9(7.5)$ & $59(49.2)$ & $52(43.3)$ & 2.36 & $9^{\text {th }}$ \\
Use of clean coagulating pan & $6(5.0)$ & $46(38.3)$ & $68(56.7)$ & 2.52 & $4^{\text {th }}$ \\
Use of formic acid for coagulation of latex & $5(4.2)$ & $35(29.2)$ & $80(66.7)$ & 2.6 & $2^{\text {nd }}$ \\
Fertilizer application and usage & $8(6.7)$ & $53(44.2)$ & $59(49.2)$ & 2.42 & $8^{\text {th }}$ \\
Recommended planting time and space & $32(26.7)$ & $32(26.7)$ & $58(46.7)$ & 2.20 & $11^{\text {th }}$ \\
Marketing information & $2(1.7)$ & $45(37.5)$ & $73(60.8)$ & 2.59 & $3^{\text {rd }}$ \\
Pest and disease control measures & $6(5.0)$ & $52(43.3)$ & $62(51.7)$ & 2.47 & $5^{\text {th }}$ \\
Use of ammonia for preservation of latex & $3(2.5)$ & $29(24.2)$ & $88(73.3)$ & 2.71 & $1^{\text {st }}$ \\
Intercropping with arable crops & $67(55.8)$ & $25(20.8)$ & $28(23.3)$ & 1.69 & $12^{\text {th }}$ \\
Tapping techniques & $3(2.5)$ & $61(50.8)$ & $56(46.7)$ & 2.44 & $6^{\text {th }}$ \\
Source: Field Survey, 2016 & & & & & \\
\hline
\end{tabular}

Table 5: Distribution of the respondents according to the constraints to rubber production

\begin{tabular}{|c|c|c|c|c|c|}
\hline Constraints & Very severe $(\%)$ & Severe $(\%)$ & Not severe $(\%)$ & Mean & Rank \\
\hline Low market prices for rubber & $51(42.5)$ & $57(47.5)$ & $12(10.0)$ & 2.32 & $8^{\text {th }}$ \\
\hline High cost of labour & $76(63.3)$ & $39(32.5)$ & $5(4.2)$ & 2.59 & $5^{\text {th }}$ \\
\hline Low yield problem & $64(53.3)$ & $44(36.7)$ & $12(10.0)$ & 2.43 & $7^{\text {th }}$ \\
\hline High cost of agrochemicals for latex processing & $41(34.2)$ & $72(60.0)$ & $7(5.8)$ & 2.28 & $11^{\text {th }}$ \\
\hline Scarcity of agrochemicals & $22(18.3)$ & $57(47.5)$ & $41(34.2)$ & 1.84 & $14^{\text {th }}$ \\
\hline Lack of adequate market for rubber latex & $60(50.0)$ & $38(31.7)$ & $22(18.3)$ & 2.32 & $8^{\text {th }}$ \\
\hline Fire outbreaks on plantations & $87(72.5)$ & $22(18.3)$ & $11(9.2)$ & 2.63 & $3^{\text {rd }}$ \\
\hline Lack of adequate credit facilities for rubber farmers & $84(70.0)$ & $32(26.7)$ & $4(3.3)$ & 2.67 & $2^{\text {nd }}$ \\
\hline Unavailability/High cost of improved planting materials & $44(36.7)$ & $62(51.7)$ & $14(11.7)$ & 2.25 & $13^{\text {th }}$ \\
\hline Problem of land tenure/small farm size & $98(81.7)$ & $16(13.3)$ & $6(5.0)$ & 2.77 & $1^{\text {st }}$ \\
\hline Poor contact with extension agents/source of information & $8(6.7)$ & $13(10.8)$ & $99(82.5)$ & 1.24 & $15^{\text {th }}$ \\
\hline Pest and disease attacks & $48(40.0)$ & $56(46.7)$ & $16(13.3)$ & 2.27 & $12^{\text {th }}$ \\
\hline Use of low quality planting materials & $57(47.5)$ & $45(37.5)$ & $18(15.0)$ & 2.32 & $8^{\text {th }}$ \\
\hline Inadequate storage facilities & $82(68.3)$ & $31(25.8)$ & $7(5.8)$ & 2.62 & $4^{\text {th }}$ \\
\hline Unavailability of simple latex processing implements & $68(56.7)$ & $42(35.0)$ & $10(8.3)$ & 2.48 & $6^{\text {th }}$ \\
\hline
\end{tabular}

Source: Field Survey, 2016

The constraint of fire outbreaks on plantation (2.63) could be attributed to wild fires around plantations and also the inability of farmers to adopt fire tracing systems. This agrees with the findings of Otene et al. (2011), which showed that majority of the respondents do not practice thinning and fire tracing respectively as a result of inadequate labour, and rubber farming is labour-intensive which when attacked by fire could lead to complete death of the trees and the result is low yield.

Problem of inadequate storage facilities with mean score of 2.62 was one of the constraints identified by the farmers. Attractive prices for natural rubber have to do with storage facilities to avoid chances of produce adulteration. Studies conducted by Uraih et al. (2006) identified high cost associated with the use of cemented surface and other improved storage facilities as the problem faced by rubber farmers in the rubber belt of Nigeria. Shortage and high cost of labour (2.59) was another major constraint identified by the farmers. This is as a result of the fact that the rubber growing belt is in the oil belt of Nigeria where the active population are attracted to, leaving rubber cultivation to the older and aged population as reported by Abolagba and Giroh (2006). The attendant consequence may be a reduction in hectarage under cultivation and declining productivity.
Low market prices for rubber with mean score of (2.32) was another constraint identified by the farmers. The result is in agreement with Abolagba et al. (2003) who reported inaccurate pricing of natural rubber which leads to low farm income as a disturbing problem of the rubber industry. This is may be due to the activities of the middlemen who pass wrong price signals to the unsuspecting farmers. Poor prices offered may be a disincentive to rubber farmers leading to decline in production.

\section{Test of Hypothesis}

The test of the relationship between respondent's socio economic characteristics and their extension needs was determined using the Pearson Product Moment Correlation analysis and the result is presented in Table 6 . The result indicates that there exists a positive, significant correlation between the

Table 6: Relationship between socioeconomic characteristics and perceived extension needs

\begin{tabular}{llll}
\hline Variables & Pearson $(r)$ & P-Value & Remark \\
\hline Age & $0.199 *$ & 0.029 & Significant \\
Educational level & $-0.273^{* *}$ & 0.003 & Significant \\
Farm Size & -0.063 & 0.494 & Not Significant \\
Household Size & 0.110 & 0.230 & Not Significant \\
Years of farming & -0.021 & 0.822 & Not Significant \\
experience & & & \\
\hline Source: Field Survey, 2016 & \\
*Correlation is significant at 0.05 level (2-tailed) \\
** Correlation is significant at the 0.01 level (2-tailed)
\end{tabular}


ages of the respondents and their extension needs $(r=0.199: p>0.05)$. This implies that older farmers would require more extension teachings, and this may be because they do not have access to more current sources of information like the internet; and also the literacy level of the older farmers might mean that they require more extension education than their younger counterparts in forms that are comprehensible to them. Furthermore, the educational level of the farmers had a negative, significant relationship with the extension needs of the farmers $(r=-0.273, p>0.01)$. This implies that the lower the level of education acquired by the respondents, the higher would be the level of teachings required on improved rubber farming techniques. This may be because the more educated farmers have access to readily available information that will help them solve their extension needs unlike the less educated farmers who may not have access to sources of information like the internet. Education is a very important variable in farm production. According to Ogunsumi and Adeyeye (2002), educated farmers have more access to information on farm improvement techniques and credit than their non-educated counterparts.

The findings further revealed that farm size $(r=-0.063: p>0.05)$ and years of farming experience $(r=-0.021: p>0.05)$ had negative correlation to the extension needs of the farmers, though not significant. This implies that the smaller the farm size and the fewer the years of farming experience of the farmers, the more their extension needs. This may be due to the fact that farmers with less farm size and few farming experience are new to farming and have more need for extension services than those with larger farm size and more farming experience, who are already established farmers.

\section{CONCLUSION}

The study showed that rubber farming was still practiced mainly by the middle aged populace. Most of the farmers had small farm holdings. Although the study revealed that extension agents were very active among the farmers, but the farmers still make use of informal sources of information in their production. The farmers cultivate a mixture of both local and exotic clones in their farms and practice agro-forestry systems for income diversification. The farmers need production information on the use of formic acid for latex coagulation, use of ammonia for latex preservation and marketing information. The major constraints to rubber production in the study area were problem of land tenure/small farm size, lack of adequate credit facilities, fire outbreaks, and inadequate storage facilities among others. The result of PPMC showed a positive and significant relationship with age of the farmers and negatively significantly correlated with level of education.

\section{RECOMMENDATIONS}

Based on the findings of this study, the following recommendations were made:

1. Youths or younger farmers should be encouraged into rubber farming in order to provide for future maintenance of rubber plantations.

2. Dissemination of innovation should be carried out through the informal channels like farmer groups, cooperative society, contact farmers, since majority of these farmers prefer these channels to formal sources.

3. The extension personnel should be trained and retrained regularly in rubber production technique in order to deliver effectively to the farmers.

4. Demonstration method should be used by the extension agents to train the farmers on techniques of production that they lacked skills to practice as indicated by them, e.g., use of ammonia for preservation of latex, use of ethel to stimulate latex yield, use of formic acid for coagulation of latex, amongst others.

5. Credit facilities should be provided for farmers by government and financial institutions to acquire inputs and engage in agroforestry practices which will boost their income.

6. Farmers should be given educational support through farmers' field school. This is because education will enable them to have access to information that can improve their production.

\section{ACKNOWLEDGEMENTS}

The authors wish to thank Madam Okonji Adaeze, Zonal Manager, Delta State Agricultural Development Program (ADP), Agbor (08037536223) and some of the field extension agents Mr. Mike Dibia (08025119291) Mr. Austin, (08162597269) and Mr. Chris (08068399647) for their contributions in giving us information on the species and varieties of Rubber that we work with and the assistance rendered to obtain the data from the farmers.

\section{REFERENCES}

Abolagba E.O. and Giroh D.Y. (2006). Constraints to sustainable development of rubber industry in Nigeria: A case study of Delta state. Moor Journal of Agriculture, 7 (1), $42-48$

Abolagba E.O., Aigbekaen E.O. and Omokhafe K.O. (2003). Farm-gate marketing of natural rubber in the south east rubber growing zone of Nigeria. Nigeria Journal of Agriculture \& Rural Development, 6, 40-48

Agwu A.E. (2004). Factors influencing adoption of improved cowpea production technologies in Nigeria. Journal of International Agricultural \& Extension Education, 11 (1), 81-88

Aigbokaen E.O., Imarhiagbe E.O. and Omokhafe K.O. (2000). Adoption of some recommended agronomic practices of natural rubber in Nigeria. Journal of Agriculture, Forestry \& Fisheries, 1\& 2, 51-56

Akukwe T.I. (2020). Household food security and its determinants in agrarian communities of Southeastern Nigeria. Agro-Science, 19 (1), 54-60. DOI: https://dx.doi.org/10.4314/as.v19i1.9 
Banmeke T.O.A. and Olowu T.A. (2005). Accessibility of Women Farmers to Agricultural Information in South Western Nigeria. South African Journal of Agricultural Extension, 34 (2), 237-246

Banmeke T.O.A and Omoregbee F.E. (2009). Farmers perception of the factors militating against rubber production in Edo and Delta States of Nigeria. International Journal of Agricultural Economics \& Rural Development, 2 (2), 33-39

Delabarre M.A. and Serier J.B. (2000). The Tropical Agriculturalist: Rubber. Published in Cooperation with the CTA, The Netherlands, Macmillan Education Ltd

Delta State Ministry of Agriculture (2000). Statistical Information. Delta State Printing Press, 1-3

Esekhade T.U. (2003). Effects of Phosphorus and Selected Rubber Based Cropping System on the Early Development of Rubber (Heveabrasillensis, Wild. ex. Ade juss) (Mueller argoviensis) in Acid Soil. A Ph.D. Thesis at the Department of Agronomy, Faculty of Agriculture, University of Ibadan, Nigeria

Giroh D.Y., Adebayo E.F. and Jongur A.A.U. (2013) Analysis of labour productivity and constraints of rubber latex exploitation among smallholder rubber farmers in the Niger Delta Region of Nigeria. Global Journal of Agricultural Research, 1 (3), 16-26. Published by European Centre for Research Training and Development UK (www.ea-journals.org)

Giroh D.Y., Abubakar M., Balogun F.E., Wuranti V. and Ogbebor O.J. (2006). Adoption of rubber quality innovations among small-holder rubber farmers in two farm settlements of Delta State, Nigeria. Journal of Sustainable Development in Agriculture \& Environment, 2, 74-79

Idrisa Y.L., Gwary M.M. and Shehu H. (2008). Analysis of food security status among farming households in Jere Local Government of Borno State, Nigeria. Agro-Science, 7 (3), 199-205

Ike P.C (2010). Access and loan repayment in the Delta State Agricultural Loan Scheme. Farm Management Association of Nigeria (FAMAN) Journal, 11 (1), 53-61

Iyayi A.F., Akpaka P.O. and Ukpeoyibo U. (2008). Rubber seed processing for value-added latex production in Nigeria. African Journal of Agricultural Research, 3 (7), 505-509. Available online at http://www.academicjournals.org/AJAR ISSN 1991-637X @ 2008 Academic Journals

McDonaugh J. (2004). AgREN e-mail discussion on the Implications of Rural Livelihood Diversity for ProPoor Agricultural Initiatives March $21^{\text {st }}-31^{\text {st }}$

National Population Commission, NPC (2006). National Population Census, Federal Republic of Nigeria, Official Gazette, Vol. 94, Lagos
Ogunsumi L.O. and Adeyeye V.A. (2002). Socioeconomic index for rural inhabitants of Osun state, Nigeria's policy implication for rural community participation. Nigeria Journal for Rural Sociology, 3 (1), SO-86

Okunlola J.O. (2010). Factors influencing adoption of rubber-based techniques among small-holder farmers in Delta State, Nigeria. Journal of Food, Agriculture \& Environment, 8 (2), 391-394. www.world-food.net

Omokhafe K.O. and Nasiru I. (2004). Polygene inheritance of latex yield in Heveabrasiliensis Muell Arg. Plant Genetic Resources News Letters, 140, 48-50

Ogwuche P., Umar H.Y., Esekhade T.U. and Francis S.Y. (2012). Economies of intercropping natural rubber with arable crops: a panacea for poverty alleviation of rubber farmers. Journal of Agriculture \& Social Sciences, $\mathbf{8}, 100-102$

Oladele O.I. (2006). Multilinguality of farm broadcast and agricultural information access in Nigeria, Nordic Journal of African Studies, 15 (2), 199-205

Omo-Irabor O.O. and Olobaniyi S.B. (2013). Application of multi-criteria decision analysis and GIS techniques in vulnerability assessment of coastal inhabitants in Nigeria to crude oil production and transportation activities. In: Onsrud $\mathrm{H}$. and Rajabifard A. (eds.). Spatial Enablement in Support of Economic Development and Poverty Reduction: Research, Development and Education Perspectives. GSDI Association Press, Needham USA, 169-190

Osiebe P.E. (1999). Reasons for the Rapid Decline in Rubber Production in Ethiope West Local Government Area of Delta State. B.Agric. Thesis, University of Nigeria, Nsukka

Otene F.G., Obinne C.P. and Egwumah P.O. (2011). Evaluation of the utilization level of improved rubber management practices among farm settlers in Edo and Delta States. Journal of Agricultural Science, 2 (1), 53-60

Pierre-André O.N., Aurelie N.N., Ejolle E.E., Bénédicte C.P. and Jean-Claude B. (2010). Assessment of training needs of rubber farmers in the South-west region of Cameroon. African Journal of Agricultural Research, 5 (17), 2326-2331. Available online at http://www.academicjournals.org/AJARISSN 1991637X (C2010 Academic Journals

Uraih O.B.C., Abubakar M., Balogun F.E., Giroh D.Y., Ogbebor O.J. and Okwu U.N. (2006). Assessment of rubber quality consciousness among small holder rubber farmers in farm settlement of Edo and Delta States of Nigeria. Journal of Sustainable Tropical Agricultural Research, 19, 46-51 